\title{
Two New Species of Porphyra and their Subgeneric Relationship*
}

\author{
by Hideo MiKami**
}

三上日出夫**： 紅藻アマノリ属の二新種とその類縁について*

Received April 3, 1956

A vegetative cell of the genus Porphyra is well known to have usually a single central stellate chromatophore with one pyrenoid at the center. In 1935, however, Prof. Tokida noted that the vegetative cells of $P$. Onoi Ueda, in the monostromatic part of the frond, contained two eccentric chromatophores. Further, on this interesting fact, he reported, " $P$. Onoi represents an intermediate form between the two subgenera, Euporphyra and Diploderma, not only in having a monostromatic frond intermixed with distromatic portions but also in the structure of the chromatophore." For that reason he established a new subgenus Diplastidia on the basis of $P$. Onoi, and it was defined as follows:

\section{Subgenus Diplastidia Tokida 1935}

Frond is for the most part composed of one layer of cells containing two plastids, and in portions it is often distromatic.

Now, the cells of the following two new species, which were collected by the writer in the Hidaka Prov., Hokkaido, each contained two chromatophores as $P$. Onoi. Their diagnoses and anatomical descriptions are given here as follows:

\section{The diagnoses of the species}

Porphyra pseudocrassa Yamada et Mikami

Frons membranacea, monostromatica, orbiculata vel reniformis, marginibus vix undulatis, ad basin stipitata, cordata vel rotunda, 3-7 cm. longa, $2.5-7.0 \mathrm{~cm}$. lata, 55$82 \mu$ crassa ; cellulis vegetativis rotundato-angulatis, in sectione transversa rotundatosubrectangularibus; gelatina superficialis $10-14 \mu$ crassa; cellulis 2 -chromatophoris, substellatis (vel discoideis); dioica vel raro monoica; spermatia in antheridio 128 $\left(\frac{a}{4}, \frac{b}{4}, \frac{c}{8}\right)$, carposporae in sporocarpio $16\left(\frac{a}{2}, \frac{b}{2}, \frac{c}{4}\right)$.

\footnotetext{
* This report was presented at the annual meeting of the Botanical Society of Japan, held in October 1954 at Kyoto University.

** Sapporo Minami High School, Sapporo, Japan. 札幌南高等学校
} 
Japanese name: Makure-amanori (nov.).

Loc.: Harutachi, Samani, Hidaka Prov., Hokkaido; Akkeshi, Kushiro Prov., Hokkaido. (The type specimen is deposited in the Herbarium of the Faculty of Science, Hokkaido University.)

Frond membranaceous, monostromatic, orbiculate or reniform, scarcely undulate at margin, shortly stipitate, with cordate or ovate base, 3-7 cm. long, 2.5-7 cm. broad, 55$82 \mu$ thick; vegetative cells, in surface view, angular with rounded corners, somewhat regularly arranged, in cross section subrectangular with round angles, usually twice as long as broad; surface jelly $10-14 \mu$ thick; lowermost cells projecting rhizoidal

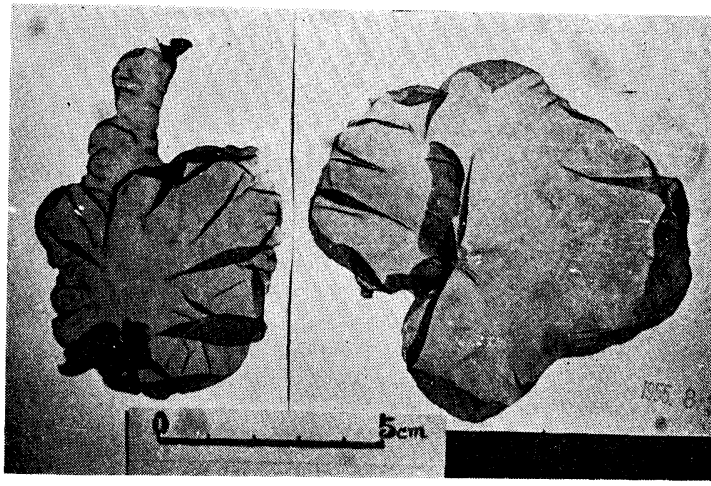

Fig. 1. Porphyra pseudocrassa Yamada et Mikami. filaments ovate or capitate; each cell containing two substellate (or discoidal) chromatophores; colour of the frond purplish red or russet; dioecious or rarely monoecious; antheridia formed within yellowish marginal zone of the upper part of the frond, containing 128 antherozoids after having divided according to the formula $128\left(\frac{a}{4}, \frac{b}{4}, \frac{c}{8}\right)$; each sporocarp containing 16 carpospores, after having divided according to the formula, $16\left(\frac{a}{2}, \frac{b}{2}, \frac{c}{4}\right)$.

The present species grows on rocks in the upper sublittoral zone. The frond is as a rule orbiculate or reniform with scarcely undulate margin, and always monostromatic. In outer appearance, the present new species shows a considerable resemblance to $P$. crassa Ueda, described and figured by Prof. Ueda (1932) and Prof. Tanaka (1952). But it differs from the latter in the following anatomical characters. That is, according to Prof. Tanaka, in $P$. crassa Ueda each cell contains a star-shaped chromatophore with several slender arms radiating in all directions (1952, p. 56, Fig. 26,b), while this species contains two substellate (or discoidal) chromatophores. This peculiar feature is also ascertained in the basal cells which produce rhizoidal filaments, as shown in Fig. 2, 1-2. In the structure of the chromatophore, the present materials agree rather with $P$. Onoi, but differ entirely from it in being generally dioecious, in the divisional mode of antheridia and sporocarps, and in having the monostromatic thallus. On the other hand, present species shows some resemblance to some Californian species, Porphyra lanceolata (Setch. et Hus) G. M. Smith and P. pulchra Hollenberg in the structure of the chromatophore and in having the monostromatic thallus. But it is distinguishable from Smith's species by the difference of divisional mode of sporocarps outer appearances, and 
from Hollenberg's species by outer appearances and its dioecious thallus. As far as the present writer's observations show, this species is dioecious, but rarely monoecious. Its sporocarps and antheridia are both found along the marginal turn-up portion of the frond.
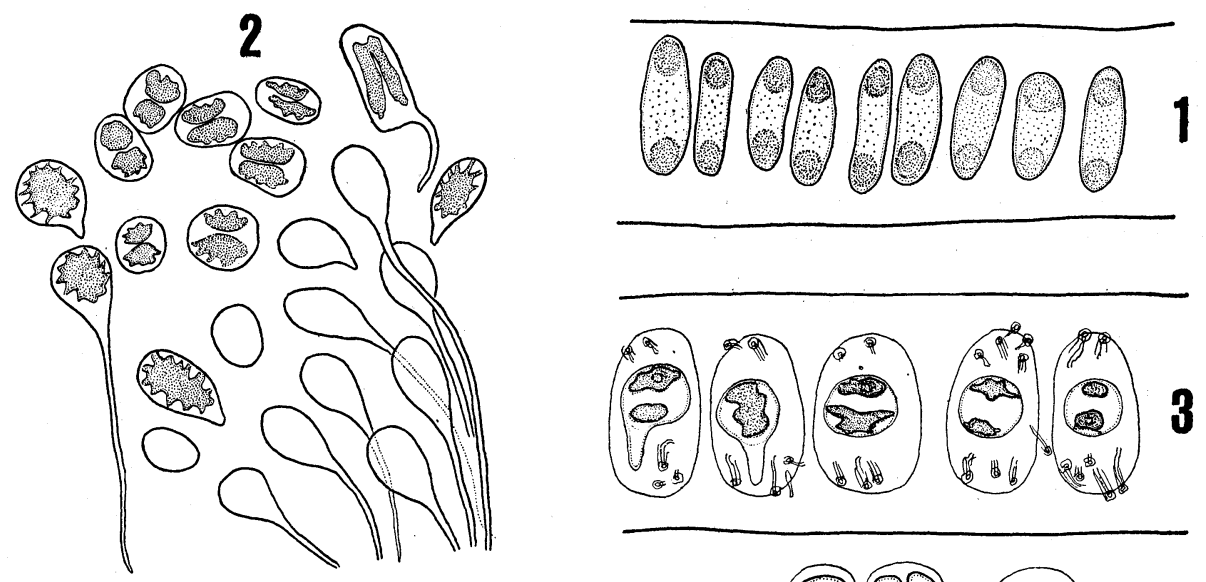

7
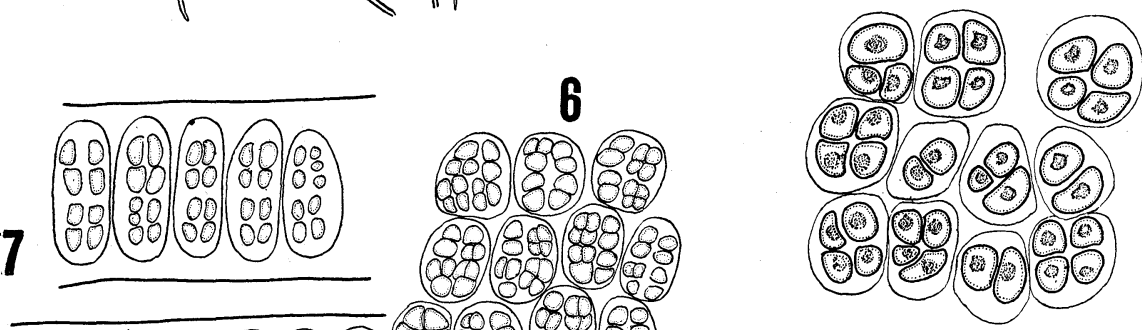

4

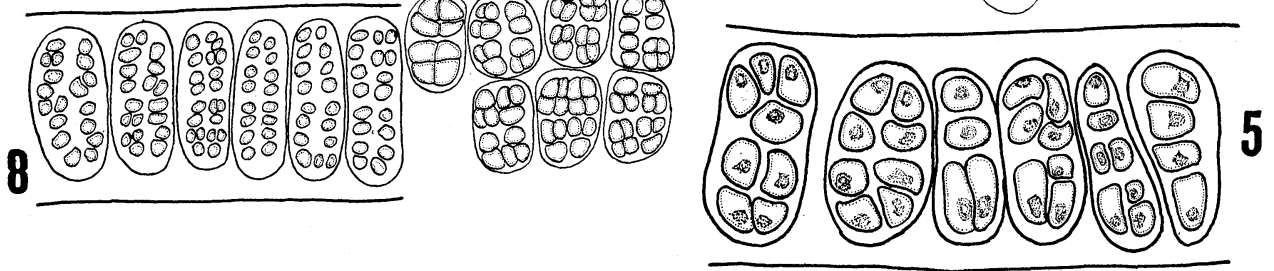

Fig. 2. Porphyra pseudocrassa Yamada et Mikami.

1: Section of vegetative portion, with two chromatophores in each cell.

2: Surface view of lower cells with rhizoidal filaments (dried).

3: Section of lower cells with rhizoidal filaments.

4: Surface view of cystocarpic portion.

5: Section of cystocarpic portion.

6: Surface view of antheridial portion.

7-8: Section of antheridial portion.

$$
2, \times 32.5 \text {. } \quad 1,3-8, \times 370 \text {. }
$$

\section{Porphyra punctata Yamada et Mikami}

Frons membranacea, monostromatica vel distromatica, ovata vel oblongo-ovata vel lineali-lanceolata, marginibus undulatis, foraminibus rotundatis majoribus et minoribus perforata, ad basin stipitata, cordata vel rotunda, 8.5-18 cm. longa, 3.5$7 \mathrm{~cm}$. lata, 50-70 $\mu$ crassa; cellulis vegetativis obscure seriatis, rotundato-angulatis 
vel ellipticis; gelatina superficialis $11.5-17.5 \mu$ crassa; cellulis $1-2$ chromatophoris stellatis; dioica; spermatia in antheridio $128\left(\frac{a}{4}, \frac{b}{4}, \frac{c}{8}\right)$, carposporae in sporocarpio $64\left(\frac{a}{4}, \frac{b}{4}, \frac{c}{4}\right)$.

\section{Japanese name: Sunago-amanori (nov.)}

Loc.: Erimo, Samani, Hidaka Prov., Hokkaido. (The type specimen is deposited in the Herbarium of the Faculty of Science, Hokkaido University.)

Frond membranaceous, monostromatic or distromatic, ovate or oblong-ovate often linear, with undulate margins, perforate, shortly stipitate, with cordate or ovate base, lustrous, $8.5-18 \mathrm{~cm}$. long, 3.5$7 \mathrm{~cm}$. broad, 50-70 $\mu$ thick; vegetative cells in surface view usually round or elliptic, ca. $17 \mu$ in diameter, more or less irregularly arranged; surface jelly $11.5-17.5 \mu$ thick; vegetative cells containing one or two stellate chromatophores; dioecious; sporocarpic and antheridial patches found on tne marginal region of the different thalli; each antheridium containing 128 antherozoids, arranged in four tiers of four each in surface view, according to the formula of division, corresponding to $128\left(\frac{a}{4}, \frac{b}{4}, \frac{c}{8}\right)$; sporocarp containing 64 carpospores each after having divided according to the formula, $64\left(\frac{a}{4}, \frac{b}{4}, \frac{c}{4}\right)$; colour of the frond purplish red.

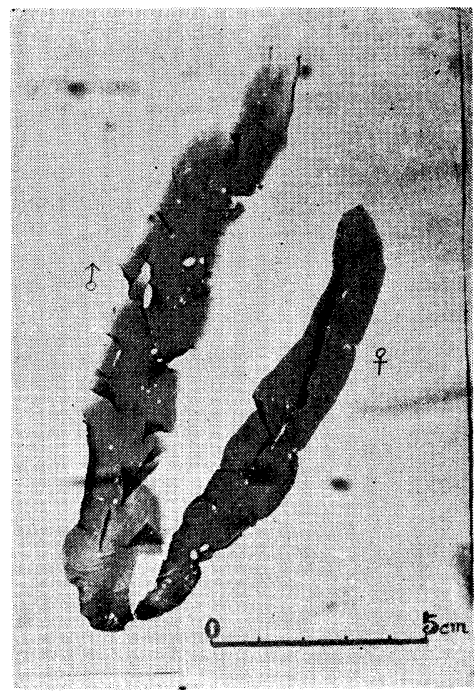

Fig. 3. Porphyra punctata Yamada et Mikami Male and female plants.

The present new species was found on rocks in the littoral zones. The shape and size of the frond are variable. The materials examined contain two forms. The one is ovate or oblong-ovate. The other has a linear frond. The fronds of the present species are for the most part monostromatic, but usually exhibit a distromatic nature in many portions of the full-grown frond. One of the leading characters of this species is that the distromatic parts can be detected by the naked eye as sandy spots. In some respect, $P$. punctata is similar to $P$. Onoi Ueda. As noted above, however, in the present species, some cells in the thallus contain a single typical chromatophore as shown in Fig. 4, 2,8. In other cells in the grown portion, the choromatophore soon divides into two which gradually separate from each other. Moreover, the present species differs from it in the divisional modes of sporocarp and antheridia. The present species is dioecious. The antheridia are formed within narrow marginal zones of the frond. Each atheridium contains 128 antherozoids, arranged in four each in surface view. The formula of these division 
corresponds to $128\left(\frac{a}{4}, \frac{b}{4}, \frac{c}{8}\right)$. The sporocarpic patches are found in the marginal region of the different thallus. Vegetative cells are often intermixed among the sporocarps. At the matured female region the short sword-cut like streaks are often observed. 'As far as the writer's observations show, the matured sporocarps contain 64 carpospores. The formula of these division corresponds to $64\left(\frac{a}{4}, \frac{b}{4}, \frac{c}{4}\right)$
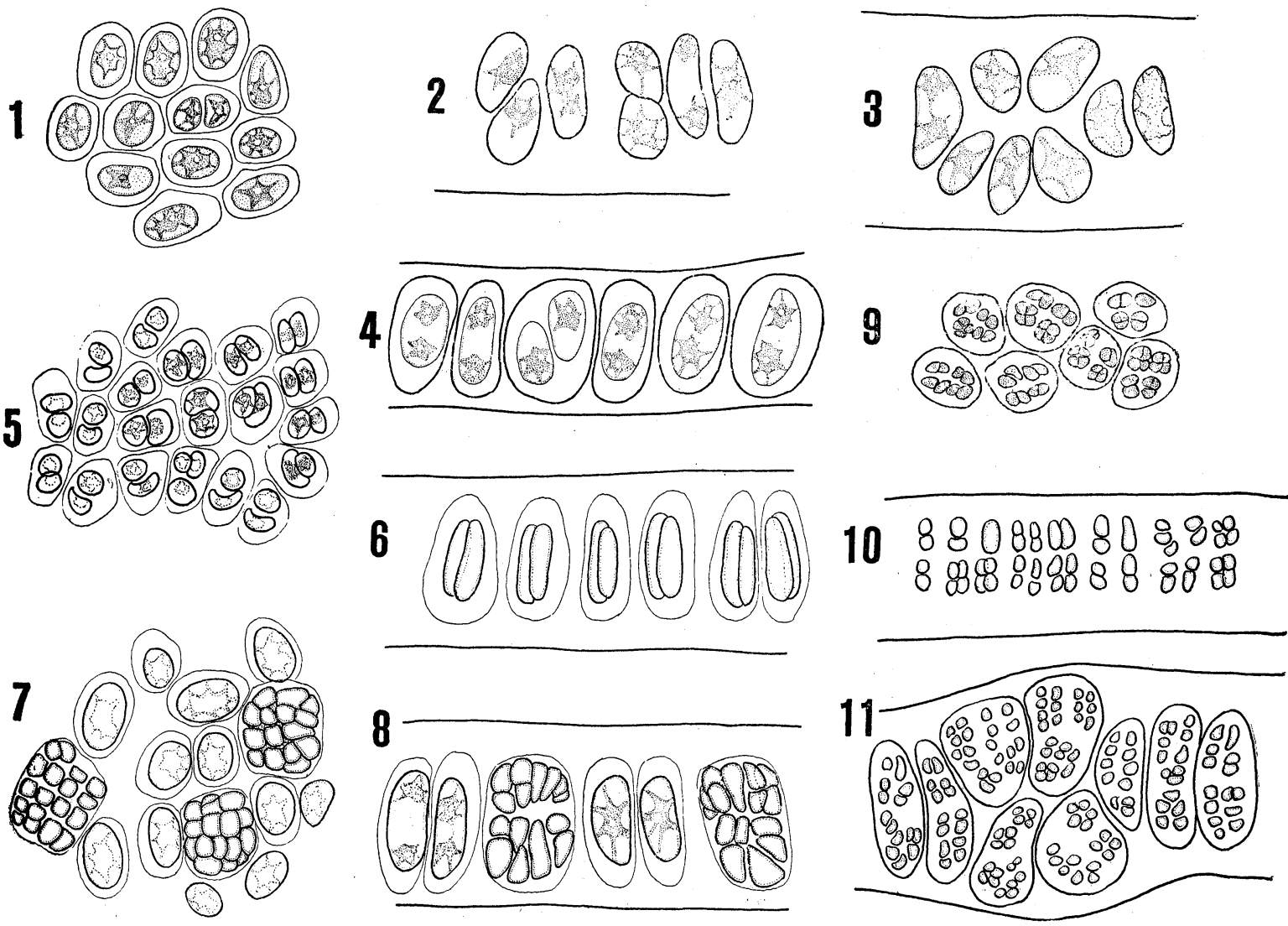

Fig. 4. Porphyra punctata Yamada et Mikami.

1: Surface view of vegetative portion.

2-4: Section of vegetative portion.

5: Surface view of young cystocarpic portion.

6: Section of the same portion.
7: Surface view of mature cystocarpic portion.

8: Section of the same portion.

9: Surface view of antheridial portion.

10-11: Section of antheridial portion. $\times 370$.

\section{Subgeneric relationship}

When the subgenus Diplastidia was established (1935), there was known only one species, $P$. Ono $i$ Ueda. As noted above, however, P. Onoi, P. pseudocrassa, $P$. pulchra, $P$. lanceolata, $P$. punctata, etc. resemble each other in the possession of the cells containing two plastids. As pointed out by Prof. Tokida, this character 
seems to the writer to be that of an intermediate form between two subgenera, Euporphyra and Diploderma.

Judging from the resemblance in their habit, they are to be placed under the subgenus Diplastidia. Therefore, I propose that it is necessary to expand the definition of Diplastidia as follows:

\section{Diplastidia}

(1) Frond is only monostromatic, or in portions it is often distromatic.

(2) Each cell contains two plastids, or in portions a single plastid.

In conclusion, the writer wishes to tender his best thanks to Prof. Y. Yamada for his kind direction during this work.

\section{Resume}

(1) In this paper is reported the discovery of two new species of Porphyra, $P$. pseudocrassa, and $P$. punctata.

(2) The definition of Diplastidia (subg.) is expanded.

\section{Principal References}

1. Hus, H. T. A., Proc. Calif. Acad. Sci. 3d ser., Botany, 2: 173-240 (1902). 2, Rosenvinge, L. K., Groenlands Havalger. Meddel. om Groenland 3 (1893). 3. Smith, G. M., Marine algae of: the Monterey Peninsula. Stanford Univ. Press, 168-175 (1943). 4. Tanaka, T., Mem. Fac. Fish., Kagoshima Univ. 2 (2): 1-92 (1952). 5. Taylor, W. R., Michigan Univ. Studies Sci. Series 13 (1937). 6. Tokida, J., Phyc. Observ., II, “On the structure of Porphyra Onoi Ueda" (1935). The Mar. Alg. of Southern Saghalien (1954). 7. Ueda, S., Bull. Jap. Sci. Fish. 28 (1) (1932).

\section{Cytotaxonomical Notes on the Ranunculus acris Group in Japan}

\section{by Hiroshi HarA* and Sachiko KUROSAWA*}

\section{原＼cjkstart寛*・黒沢幸子*：日本産キンポウゲ近似種の細胞分類学的所見}

Received June 13, 1956

The Ranunculus acris group is very variable in Japan as well as in continental Eurasia. From outer morphological characters, the senior author ${ }^{4}$ has recognized 3 species with a few varieties from Japan in this group, excluding $R$. yakushimensis Masamune.

Among them, R. japonicus Thunberg is the commonest race in Japan widely

\footnotetext{
* Botanical Institute, Faculty of Science, University of Tokyo, Hongo, Tokyo.
} 